\title{
A National Voice for Professional Foresters - CFPFA Canadian Federation of Professional Foresters Associations
}

This is the first of a planned series of articles intended to raise member awareness regarding the role and activities of the Canadian Federation of Professional Foresters Associations (CFPFA). The CFPFA is a National Association of Professional Forester Associations in British Columbia, Alberta, Ontario, Quebec and New Brunswick. The CIF/IFC is a member representing those provinces without a Provincial Association. CIF/IFC serves as secretariat for the group. The CFPFA was established in 1981 to provide a forum for communication and cooperation among provincial associations of Professional Foresters and the CIF/IFC.

Over the years, activity of CFPFA has involved one annual meeting which has served primarily as a forum for information exchange between members. In addition, the CFPFA working on behalf of its member agencies became involved in a number of national level projects. The most noteworthy of these involved the development of a national accreditation process for university baccalaureate programs in forestry in cooperation with the Association of University Forestry Schools of Canada (AUFSC). One of the purposes of accreditation was to meet minimum academic standards for registration in the Provincial Associations. This involved development of a national policy for accreditation as well as implementation and monitoring of the program.

The Canadian Forestry Accreditation Board (CFAB) was established as an arm of CFPFA to implement and monitor accreditation. By 1993, the seven universities offering forestry degree programs had been accredited by CFAB. An eighth university, will be completing its requirements for accreditation in 1998 . National accreditation of these programs

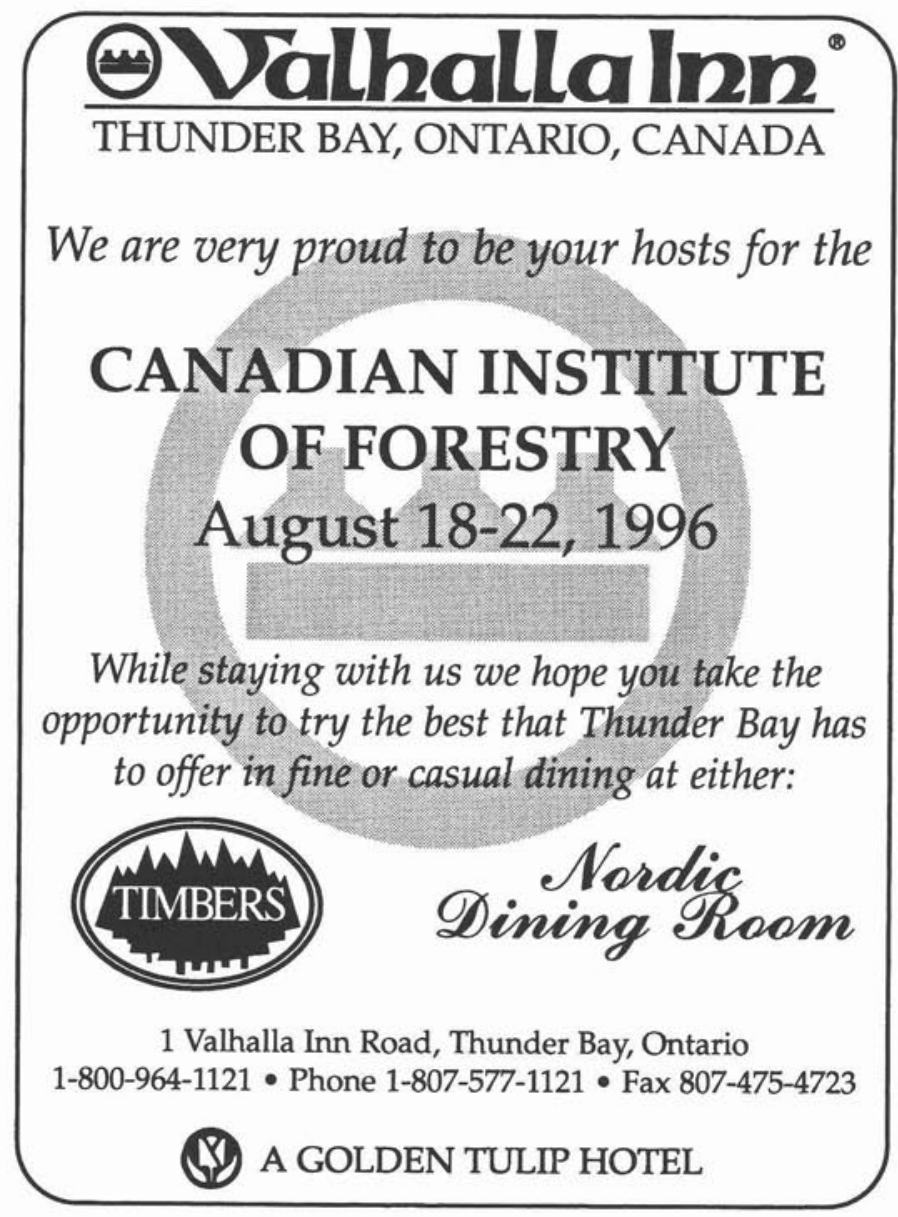

was an important step along the road to maturity for the forestry profession in Canada.

At the present time, CFPFA is renewing its Terms of Reference and is developing an Action Plan for 1996/97. Communication and information exchange between members is still considered to be a primary objective of CFPFA. To that end, the group plans to step up communications efforts over the course of the next year. In addition, the National Accreditation policy referred to above is being revised in cooperation with the members of AUFSC. A revised draft policy for national accreditation will be circulated to the members of CFPFA in the spring of 1996. If they have not already done so, member associations should prepare for a review of the draft policy with a critical analysis of their membership standards. How do member associations define "Professional Forester?" Are current standards for registration overly restrictive? Is it possible to attain greater uniformity in the standards for registration among member associations? Should specialist categories be added to the national standards? Should additional competencies (i.e., communications, professionalism and ethics) be added to the minimum standards?

Review of the national accreditation policy is a high priority undertaking for CFPFA in 1996.

Other activities for CFPFA are being considered and a complete Terms of Reference and Action Plan will be published in the next issue of The Forestry Chronicle. Areas of interest include National Standards of Practice for Professional Foresters, Summary Comparison of Continuing Education Programs, cross-jurisdictional Use of Title and International Credentials.

With the many changes and challenges facing the profession, I believe that a national forum for professional foresters is needed. However, a clear action plan combined with more regular communication and dedicated effort is needed. We hope to build on the level of success achieved in the area of national accreditation. Chair, CFPFA 


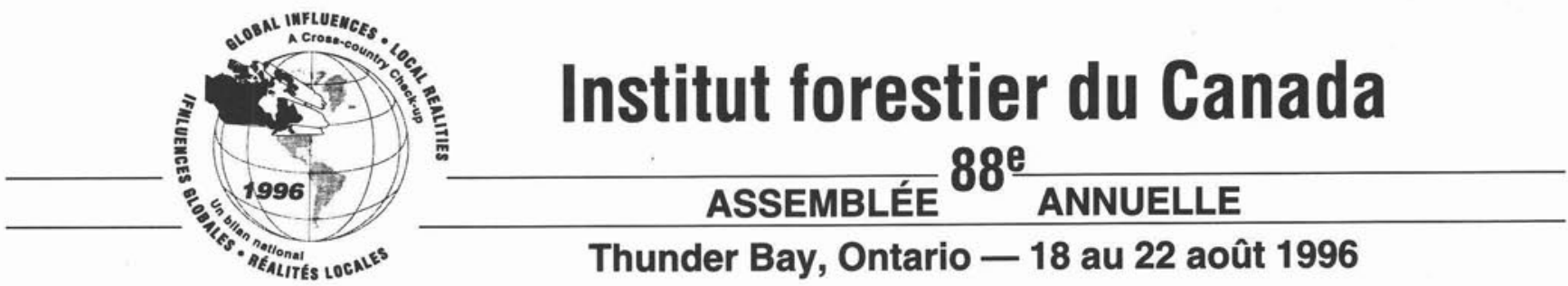

Thunder Bay est le site de conférences depuis 1815, alors que le grand rendezvous attirait les voyageurs, les guides amérindiens et les partenaires écossais de la Compagnie du Nord-Ouest. Participez à une intéressante conférence nationale de foresterie du 18 au 22 août 1996, à Thunder Bay, une ville bâtie au pied de la magnifique chaîne de montagnes Nor'Wester, sur les rives du spectaculaire Lac Supérieur. Venez découvrir pourquoi les gens se réunissent à Thunder Bay depuis près de 200 ans.

\section{Vous êtes invité à participer à une conférence stimulante sur le plan professionnel mise en valeur par:}

- Un programme remarquable s'appuyant sur une importante composante d'excursions techniques et de sessions techniques

- Une réunion conjointe d'une journée portant sur la $7^{\mathrm{e}}$ conférence nord-américaine sur le caribou

- Un programme d'activités sociales et pour les conjoints des plus complet: participez aux événements traditionnels du vieux Fort William

- Une session de communications, une exposition commerciale et un déjeuner des anciens

- Un centre de conférence renommé du centre du Canada disposant d'une grande variété de commodités qui en font également une destination de vacances.

\section{Influences mondiales • Réalitiés locales • Une vérification pan-canadienne}

Un programme de conférences illustrant les techniques les plus avant-gardistes et les plus innovatrices en aménagement forestier du nord-ouest de l'Ontario et du Canada. Un choix $d^{\prime}$ excursions techniques est disponible en fonction des sous-thèmes.

\section{Certification des forêts}

Une revue des circonstances qui ont agit comme catalyseur des différents schémas de certification ainsi qu'un portrait national des différents processus et expériences.

\section{Aménagement des écosystèmes}

Venez entendre et voir comment les gestionnaires font face à la biodiversité et à la productivité des écosystèmes en fonction de différentes échelles.

\section{Forêts modèles/de démonstration}

Les essais des nouvelles techniques et des paradigmes dans un contexte public constituent les éléments clés des forêts de démonstration. Les toutes dernières informations sur certaines forêts modèles et de démonstration seront abordées au cours des sessions.

\section{Territoires protégés}

Un sommaire des récentes initiatives entreprises au Canada au moyen d'interessantes réalisations touchant la création, la gestion et l'utilisation des territoires protégés.

Pour de plus amples informations, veuillez contacter

Inscription aux conférences . . . . . . . Paul Charrette. . . . (807) 343-8502 . . . . . . Téléc. (807) 343-8116

Sessions de communications . . . . . . . Nancy Luckai . . . . . (807) 343-8624 . . . . . . Téléc. (807) 343-8116

Sollicitation d'exposés ............ Len Meyer ........ (807) 343-8445 . . . . . . Téléc. (807) 343-8116

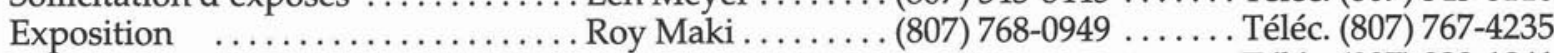

Conférence Caribou ............. . Gerry Racey....... (807) 939-3102 ....... Téléc. (807) 939-1841 